Jurnal Geocelebes Vol. 5 No. 2, Oktober 2021, 102 - 115

\title{
PENERAPAN METODE TREND SURFACE ANALYSIS UNTUK PEMISAHAN ANOMALI RESIDUAL DAN REGIONAL PADA DATA GAYABERAT
}

\author{
Purwaditya Nugraha*, Nono Agus Santoso \\ Program Studi Teknik Geofisika Institut Teknologi Sumatera Lampung Indonesia \\ *Corresponding author. Email: purwaditya.nugraha@tg.itera.ac.id
}

Manuscript received: 10 June 2021; Received in revised form: 30 July 2021; Accepted: 2 August 2021

\begin{abstract}
Abstrak
Pemisahan anomali regional dan anomali residual pada data gayaberat merupakan bagian penting dalam melakukan interpretasi data gayaberat. Proses ini bertujuan untuk mendapatkan anomali gayaberat yang sudah berasosiasi dengan target eksplorasi. Metode Trend Surface Analysis merupakan teknik pendekatan matematika pada bidang kebumian yang dapat digunakan untuk memisahkan peta kedalam komponen regional dan komponen lokal. Penerapan metode ini ke dalam data gayaberat dapat digunakan untuk memisahkan anomali regional dan anomali residual. Proses pengolahan metode trend surface analysis dapat dilakukan dengan menggunakan microsoft excel. Metode ini diuji terlebih dahulu pada data gayaberat sintetis, tujuan pengujian ini adalah untuk mengetahui performa metode trend surface analysis dalam melakukan pemisahan anomali. Berdasarkan hasil pengujian metode trend surface analysis pada data gayaberat sintetis didapatkan bahwa metode ini cukup baik dalam memisahkan anomali regional dan anomali residual. Hal ini dibuktikan pada pola anomali yang sudah sama antara anomali gayaberat regional hasil pemisahan anomali metode trend surface analysis dengan anomali regional hasil data sintetis. Pola anomali yang sama juga dapat dilihat pada anomali residual hasil pemisahan anomali metode trend surface analysis dengan anomali residual hasil data sintetis. Penerapan metode trend surface analysis pada data lapangan telah dilakukan dengan menghasilkan anomali regional dan anomali residual. Metode ini sangat baik dalam memisahkan anomali regional dan anomali residual terutama pada anomali regional yang berada pada kedalaman dalam.
\end{abstract}

Kata Kunci: Anomali Regional; Anomali Residual; Pemisahan anomali; Trend Surface Analysis.

\begin{abstract}
The separation of regional anomalies and residual anomalies in gravity data is an important part in interpreting gravity data. This process aims to obtain gravity anomalies that have been associated with exploration targets. The trend surface analysis method is a mathematical approach to the earth field that can be used to separate maps into regional components and local components. The application of this method into gravity data can be used to separate regional anomalies and residual anomalies. The process of processing the trend surface analysis method can be done using Microsoft Excel. This method is tested first on synthetic gravity data, the purpose of this test is to determine the performance of the trend surface analysis method in performing anomaly separation. Based on the test results of the trend surface analysis method on synthetic gravity data, it was found that this method was quite good at separating regional anomalies and residual anomalies. This is evidenced by the anomalous pattern that is already the same between the regional gravity anomaly resulting from the separation of the anomaly using the trend surface analysis method danthe regional anomaly resulting from synthetic data. The same anomaly pattern can also be seen in the residual anomaly resulting from the separation of the anomaly using the trend surface analysis method with the residual anomaly resulting from synthetic data. The application
\end{abstract}


of the trend surface analysis method to field data has been carried out by producing regional anomalies danresidual anomalies. This method is very good at separating regional anomalies danresidual anomalies, especially in regional anomalies located at deep depths.

Keywords: Anomaly Separation; Regional Anomaly; Residual Anomaly; Trend Surface Analysis.

\section{Pendahuluan}

Trend analysis adalah pekerjaan seorang geolog yang menggunakan pendekatan metode matematika dalam memisahkan sebuah peta menjadi dua komponen, yaitu komponen regional dan komponen lokal (Davis, 2002). Pengukuran metode gayaberat menghasilkan anomali Bouguer yang merupakan superposisi dari anomali regional dan anomali residual (Blakely, 1995; Xu et al., 2009). Anomali Bouguer merupakan sinyal geofisika yang kompleks dimana merefleksikan kombinasi efek gravitasi di bawah permukaan yang diakibatkan oleh sumber yang berbeda kedalaman dan berbeda ukuran. Anomali Bouguer tidak dapat langsung digunakan untuk menginterpretasikan sumber penyebab anomali tersebut, sehingga perlu dilakukan pemisahan anomali Bouguer menjadi anomali regional dan anomali residual gaya berat (Abokhodair, 2011). Anomali regional merupakan anomali gayaberat yang berasosiasi dan diakibatkan oleh sumber anomali pada kedalaman dalam dan memiliki ukuran yang besar (Nishijima and Naritomi, 2017), sedangkan anomali residual adalah sumber anomali yang berasosiasi dan diakibatkan oleh sumber anomali pada kedalaman dangkal yang biasanya memiliki ukuran yang kecil (Keating and Pinet, 2011). Pemisahan anomali regional dan anomali residual adalah bagian penting dalam proses interpretasi, oleh karena itu penggunaan istilah anomali regional dan anomali residual adalah untuk memperjelas perbedaan kedua anomali tersebut yang berkaitan dengan sumber anomali dalam dan sumber anomali dangkal. Terhadap beberapa kasus, pemilihan anomali regional dapat bergantung pada anomali residual sebab anomali ini merupakan anomali yang menjadi target interpretasi (Beltrao, Silva and Costa, 1991). Pada praktiknya terdapat banyak metode untuk melakukan pemisahan anomali regional dan anomali residual, beberapa diantaranya trend surface analysis (Obasi, Onwuemesi and Romanus, 2016), Polynomial fitting (Beltrao, Silva and Costa, 1991), Non Linier Fitting (Keating and Pinet, 2011), dan wiener filtering (Pawlowski and Hansen, 2002). Secara umum metode pemisahan anomali regional dan anomali residual dapat dikelompokan menjadi beberapa kelompok, diantaranya berdasarkan grafis, spektral dan polinomial (Nettleton, 2014).

Metode pemisahan anomali berdasarkan grafis merupakan mtode yang lambat dan tidak dapat dilakukan dengan otomatis karena perlu memperhatikan peta kontur dengan seksama, selain itu proses ini hanya memberikan bobot pada hanya data anomali regional dan hanya bergantung pada intuisi dari interpreter sehingga bersifat subjektif (Skeels, 1967; Gupta and Ramani, 1980).

Metode spektral merupakan metoda analisis kuantitatif pada metode gayaberat dalam domain frekuensi yang mampu mengestimasi kedalaman sumber anomali berdasarkan amplitudo spektralnya (Spector and Grant, 1970; Blakely, 1995). Pada analisis data gayaberat, metode spektral telah banyak digunakan secara luas dan telah terbukti manfaatnya terutama untuk transformasi domain spasial menjadi domain frekuensi pada data gayaberat (Xu and Chen, 2018). Di sisi lain metode analisis spektal secara kuantitatif menghasilkan hasil yang lebih baik dalam menganalisis anomali regional dan anomali residual berdasarkan frekuensi yang 
terkandung pada sinyal anomali gayaberat (Beltrao, Silva and Costa, 1991). Pada proses perhitungannya, analisis spektral menghitung total energi spektrum dari sinyal anomali gayaberat dalam domain frekuensi kemudian mengeliminasi setiap anomali yang menjadi target, pada anomali regional ataupun anomali residual (Martín et al., 2011). Selain dapat dimanfaatkan pada data metode gayaberat, analisis spektral juga dapat digunakan pada geomagnetik untuk memisahkan anomali regional dan residual berdasarkan kandungan frekuensinya (Shuey et al., 1977). Manfaat lain metode analisis spektral pada data geomagnetik adalah dapat digunakan untuk menentukan kedalaman curie berdasarkan data metode geomagnetik (Selim and Aboud, 2014).

Metode polinomial atau dikenal dengan trend surface analysis mengasumsikan bahwa persamaan polinomial dapat memodelkan bentuk bidang bumi yang kehalusannya dikontrol oleh orde polinomialnya (Simpson, 1954; Abdelrahman et al., 1985). Metode polinomial sejatinya adalah sebuah metode yang berupaya memodelkan sebuah model dengan pendekatakan persamaan matematis yaitu persamaan polinomial. Semakin tinggi orde polinomial maka maka hasil perhitungan akan semakin mirip dengan model yang akan dimodelkan, hanya saja model noise juga ikut termodelkan dalam proses pemodelan. Oleh karena itu polinomial orde rendah mungkin tidak cukup untuk memodelkan model yang sangat halus dan kecil tetapi dampaknya noise yang ukurannya kecil dan halus ikut tidak dimunculkan (Abdelrahman et al., 1985). Proses perhitungan metode polinomial tergolong mudah karena dapat dilakukan tanpa harus menyusun kode pemrograman. Perhitungan cukup dilakukan dengan penyusunan matriks yang dapat dilakukan tanpa menggunakan perangkat komputer sekalipun (Obasi, Onwuemesi and Romanus, 2016).
Berdasarkan latar belakang yang telah menjelaskan berbagai jenis metode pemisahan anomali yang memiliki beberapa kelebihan dan kekurangan maka pada tulisan ini diusulkan penerapan metode trend surface analysis atau polinomial untuk memisahkan anomali regional dan anomali residual pada data anomali gayaberat atau anomali Bouguer dengan tujuan melakukan pemisahan anomali tersebut menggunakan perhitungan yang sederhana.

\section{Tinjauan Pustaka dan Metode Kalkulasi}

Anomali Bouguer adalah akumulasi dan kombinasi dari anomali regional dan anoali residual. Anomali regional merupakan anomali yang berasosiasi dengan sumber anomali yang dalam dan besar sedangkan anomali residual merupakan anomali yang berasosiasi dengan sumber anomali yang kecil dan dangkal (Unwin, 1978; Abdelrahman et al., 1985; Guo et al., 2013; Obasi, Onwuemesi and Romanus, 2016), maka dapat didekati anomali Bouguer dengan sebuah persamaan sebagai berikut:

$g_{B}=g_{R}+g_{r}$

dengan

$g_{B}, g_{R}$, dan $g_{r}$ adalah anomali Bouguer, anomali regional, dan anomali residual berturut-turut. Asumsikan persamaan di atas dengan persamaan baru berupa

$g_{B}=G_{i j}$

$g_{R}=a x_{i}+b y_{j}+c$

$g_{B}=e_{i j}$

maka persamaan (1) akan menjadi persamaan baru sebagai berikut:

$G_{i j}=\left(a x_{i}+b y_{j}+c\right)+e_{i j}$

dengan

$G_{i j}$ adalah anomali Bouguer, $x_{i}$ adalah koordinat pengukuran pada arah-x, $y_{j}$ adalah koordinat pengukuran pada arah- 
$\mathrm{y}, e_{i j}$ adalah anomali residual, dan $a, b, c$ adalah konstanta polinomial.

Tujuan perhitungan ini adalah untuk mendapatkan anomali residual $e_{i j}$, maka persamaan (5) dapat diubah menjadi persamaan berikut:

$e_{i j}=G_{i j}-\left(a x_{i}+b y_{j}+c\right)$

Berdasarkan persamaan (6) perhitungan belum dapat dilakukan karena terdapat konstanta yang belum memiliki nilai, yaitu konstanta $a, b$, dan $c$. Mendapatkan konstanta tersebut dapat dilakukan dengan melakukan jumlah kuadrat (sum of the square) dari persamaan anomali residual. Perhitungan tersebut dapat dengan persamaan baru, misalkan $S$ adalah jumlah kuadrat dari anomali residual, maka akan menghasilkan persamaan baru sebagai berikut:

$$
\begin{aligned}
& S=\sum_{i, j=0}^{N} e_{i j}^{2} \\
& S=\sum_{i, j=0}^{N}\left[G_{i j}-\left(a x_{i}+b y_{j}+c\right)\right]^{2}
\end{aligned}
$$

untuk mendapatkan konstanta $a, b$, dan $c$ maka persamaan jumlah kuadrat dari anomali residual perlu dilakukan minimalisasi dengan cara menurunkan jumlah kuadrat anomali residual terhadap konstanta $a, b$, dan $c$ yang hasilnya adalah sama dengan nol (0) (Unwin, 1978; Grandis and Dahrin, 2014). Minimalisasi jumlah kuadrat anomali residual dengan persamaan berikut:

$\frac{\partial S}{\partial a}=\frac{\partial S}{\partial b}=\frac{\partial S}{\partial c}=0$

Penurunan persamaan (8) terhadap $a, b$, dan $c$ kemudian menyamakannya dengan 0 menghasilkan persamaan berikut:

$$
\left\{\begin{array}{l}
\frac{\partial S}{\partial a}=2 \sum_{i, j=1}^{N}\left[G_{i j}-\left(a x_{i}+b y_{j}+c\right)\right] \cdot\left(-x_{i}\right)=0 \\
\frac{\partial S}{\partial b}=2 \sum_{i, j=1}^{N}\left[G_{i j}-\left(a x_{i}+b y_{j}+c\right)\right] \cdot\left(-y_{j}\right)=0 \\
\frac{\partial S}{\partial c}=2 \sum_{i, j=1}^{N}\left[G_{i j}-\left(a x_{i}+b y_{j}+c\right)\right] \cdot(-1)=0
\end{array}\right.
$$$$
\left\{\begin{array}{l}
2 \sum_{i, j=1}^{N}\left[G_{i j}-\left(a x_{i}+b y_{j}+c\right)\right] \cdot\left(-x_{i}\right)=0 \\
2 \sum_{i, j=1}^{N}\left[G_{i j}-\left(a x_{i}+b y_{j}+c\right)\right] \cdot\left(-y_{j}\right)=0 \\
2 \sum_{i, j=1}^{N}\left[G_{i j}-\left(a x_{i}+b y_{j}+c\right)\right] \cdot(-1)=0
\end{array}\right.
$$$$
\left\{\begin{array}{l}
\sum_{i, j=1}^{N}\left[G_{i j}-\left(a x_{i}+b y_{j}+c\right)\right] \cdot\left(-x_{i}\right)=0 \\
\sum_{i, j=1}^{N}\left[G_{i j}-\left(a x_{i}+b y_{j}+c\right)\right] \cdot\left(-y_{j}\right)=0 \\
\sum_{i, j=1}^{N}\left[G_{i j}-\left(a x_{i}+b y_{j}+c\right)\right] \cdot(-1)=0
\end{array}\right.
$$$$
\left\{\begin{array}{c}
\sum_{i, j=1}^{N}\left[-G_{i j} x_{i}-\left(-a x_{i}^{2}-b x_{i} y_{j}-c x_{i}\right)\right]=0 \\
\sum_{i, j=1}^{N}\left[-G_{i j} y_{j}-\left(-a x_{i} y_{j}-b y_{j}^{2}-c y_{j}\right)\right]=0 \\
\sum_{i, j=1}^{N}\left[-G_{i j}-\left(-a x_{i}-b y_{j}-c\right)\right]=0
\end{array}\right.
$$ 


$$
\begin{gathered}
\left\{\begin{array}{c}
\sum_{i, j=1}^{N}\left[-G_{i j} x_{i}+a x_{i}^{2}+b x_{i} y_{j}+c x_{i}\right]=0 \\
\sum_{i, j=1}^{N}\left[-G_{i j} y_{j}+a x_{i} y_{j}+b y_{j}^{2}+c y_{j}\right]=0 \\
\sum_{i, j=1}^{N}\left[-G_{i j}+a x_{i}+b y_{j}+c\right]=0
\end{array}\right. \\
\left\{\begin{array}{c}
-\sum_{i, j=1}^{N} G_{i j} x_{i}+\sum_{i=1}^{N} a x_{i}^{2}+\sum_{i, j=1}^{N} b x_{i} y_{j}+\sum_{i=1}^{N} c x_{i}=0 \\
-\sum_{i, j=1}^{N} G_{i j} y_{j}+\sum_{i, j=1}^{N} a x_{i} y_{j}+\sum_{j=1}^{N} b y_{j}^{2}+\sum_{j=0}^{N} c y_{j}=0 \\
-\sum_{i, j=0}^{N} G_{i j}+\sum_{i=1}^{N} a x_{i}+\sum_{j=0}^{N} b y_{j}+N c=0
\end{array}\right.
\end{gathered}
$$

Dengan memindahkan komponen yang bernilai negatif ke ruas kanan akan menghasilkan persamaan berikut:

$$
\left\{\begin{array}{c}
\sum_{i=1}^{N} a x_{i}^{2}+\sum_{i, j=1}^{N} b x_{i} y_{j}+\sum_{i=1}^{N} c x_{i}=\sum_{i, j=1}^{N} G_{i j} x_{i} \\
\sum_{i, j=1}^{N} a x_{i} y_{j}+\sum_{j=1}^{N} b y_{j}^{2}+\sum_{j=0}^{N} c y_{j}=\sum_{i, j=1}^{N} G_{i j} y_{j} \\
\sum_{i, j=0}^{N} a x_{i}+\sum_{j=0}^{N} b y_{j}+N c=\sum_{i, j=1}^{N} G_{i j}
\end{array}\right.
$$

Persamaan di atas dapat diubah dalam bentuk matriks sehingga persamaan barunya akan menghasilkan persamaan perkalian matrix sebagai berikut:

$$
\left[\begin{array}{ccc}
\sum_{i=1}^{N} x_{i}^{2} & \sum_{i, j=1}^{N} x_{i} y_{j} & \sum_{i=1}^{N} x_{i} \\
\sum_{i, j=1}^{N} x_{i} y_{j} & \sum_{j=1}^{N} y_{j}^{2} & \sum_{j=1}^{N} y_{j} \\
\sum_{i=1}^{N} x_{i} & \sum_{j=1}^{N} y_{j} & N
\end{array}\right]\left[\begin{array}{l}
a_{a} \\
b \\
c
\end{array}\right]=\left[\begin{array}{c}
\sum_{i, j=1}^{N} G_{i j} x_{i} \\
\sum_{i, j=1}^{N} G_{i j} y_{j} \\
\sum_{i, j=1}^{N} G_{i j}
\end{array}\right]
$$

Persamaan perkalian matriks di atas membuat perhitungan untuk mencari solusi dari konstanta $a, b$, dan $c$ menjadi lebih mudah, dengan menggunakan pendekatan linier (Menke, 2012) maka persamaan diatas dapat disederhanakan kembali menjadi bentuk sebagai berikut

$d=G m$

dengan $d$ adalah $\left[\begin{array}{c}\sum_{i, j=1}^{N} G_{i j} x_{i} \\ \sum_{i, j=1}^{N} G_{i j} y_{j} \\ \sum_{i, j=1}^{N} G_{i j}\end{array}\right]$

$G$ adalah

$$
\left[\begin{array}{ccc}
\sum_{i=1}^{N} x_{i}^{2} & \sum_{i, j=1}^{N} x_{i} y_{j} & \sum_{i=1}^{N} x_{i} \\
\sum_{i, j=1}^{N} x_{i} y_{j} & \sum_{j=1}^{N} y_{j}^{2} & \sum_{j=1}^{N} y_{j} \\
\sum_{i=1}^{N} x_{i} & \sum_{j=1}^{N} y_{j} & N
\end{array}\right]
$$

dan $m$ adalah $\left[\begin{array}{l}a \\ b \\ c\end{array}\right]$. Berdasarkan persamaan (10) maka parameter yang dicari adalah paramater $m$, paramater tersebut berisi konstanta $a, b$, dan $c$, sehingga persamaan (10) dapat diubah menjadi bentuk berikut $m=G^{-1} d$.

Tahap berikutnya adalah menentukan persamaan matriks invers dari $G$ atau menentukan $G^{-1}$. Perhitungan $G^{-1}$ dapat dilakukan dengan memanfaatkan proses perhitungan matriks $3 \times 3$.

$G^{-1}=\frac{1}{|G|} \cdot \operatorname{adj} G$

dengan adj $G$ dan $|G|$ adalah adjoin matriks $G$ dan determinan dari matriks $G$.

Determinan dari matriks $G$ dapat ditentukan dengan membentuk persamaan berikut 


$$
\begin{aligned}
|G|=\sum_{i=1}^{N} x_{i}^{2}( & \left.N \sum_{j=1}^{N} y_{i}^{2}-\sum_{j=1}^{N} y_{j} \sum_{j=1}^{N} y_{j}\right) \\
& -\sum_{i, j=1}^{N} x_{i} y_{i}\left(N \sum_{i, j=0}^{N} x_{i} y_{j}\right. \\
& \left.-\sum_{i=1}^{N} x_{i} \sum_{j=1}^{N} y_{j}\right) \\
& +\sum_{i=1}^{N} x_{i}\left(\sum_{i, j=0}^{N} x_{i} y_{j} \sum_{j=1}^{N} y_{j}\right. \\
& \left.-\sum_{i=1}^{N} x_{i} \sum_{j=1}^{N} y_{i}^{2}\right)
\end{aligned}
$$

Tahap selanjutnya untuk menghitung $G^{-1}$ adalah menentukan adjoin dari $G$, tahap tersebut dapat dilakukan dengan menghitung kofaktor dari matriks $G$ terlebih dahulu. Kofaktor dari matriks $G$ disusun dari persamaan berikut:

$$
\begin{aligned}
K_{11}= & \left(N \sum_{j=1}^{N} y_{i}^{2}-\sum_{j=1}^{N} y_{j} \sum_{j=1}^{N} y_{j}\right) \\
K_{12}= & -\left(N \sum_{i, j=0}^{N} x_{i} y_{j}-\sum_{i=1}^{N} x_{i} \sum_{j=1}^{N} y_{j}\right) \\
K_{13}= & \left(\sum_{i, j=0}^{N} x_{i} y_{j} \sum_{j=1}^{N} y_{j}-\sum_{i=1}^{N} x_{i} \sum_{j=1}^{N} y_{i}^{2}\right) \\
K_{21}= & -\left(N \sum_{i, j=0}^{N} x_{i} y_{j}-\sum_{i=1}^{N} x_{i} \sum_{j=1}^{N} y_{j}\right) \\
K_{22}= & \left(N \sum_{i=1}^{N} x_{i}^{2}-\sum_{i=1}^{N} x_{i} \sum_{i=1}^{N} x_{j}\right)
\end{aligned}
$$

$$
\begin{aligned}
K_{33}=\left(\sum_{i=1}^{N} x_{i}^{2}\right. & \sum_{j=1}^{N} y_{i}^{2} \\
& \left.-\sum_{i, j=1}^{N} x_{j} y_{j} \sum_{i, j=1}^{N} x_{j} y_{j}\right)
\end{aligned}
$$

maka didapatkanlah kofaktor dari matriks $G$ adalah sebagai berikut

$$
K=\left[\begin{array}{lll}
K_{11} & K_{12} & K_{13} \\
K_{21} & K_{22} & K_{23} \\
K_{31} & K_{32} & K_{33}
\end{array}\right]
$$

Adjoin dari matriks $G$ adalah transpose dari matriks kofaktor $G$ atau adj $G=K^{T}$, maka adjoin matriks $G$ adalah persamaan berikut

$$
\operatorname{Adj} G=K^{T}=\left[\begin{array}{lll}
K_{11} & K_{21} & K_{31} \\
K_{12} & K_{22} & K_{32} \\
K_{13} & K_{23} & K_{33}
\end{array}\right]
$$

Setelah didapatkan determinan dari matriks $G$ dan adjoin matriks $G$, maka invers matriks $G$ atau $G^{-1}$ adalah

$$
G^{-1}=\frac{1}{|G|}\left[\begin{array}{lll}
K_{11} & K_{21} & K_{31} \\
K_{12} & K_{22} & K_{32} \\
K_{13} & K_{23} & K_{33}
\end{array}\right]
$$




$$
G^{-1}=\left[\begin{array}{lll}
\frac{K_{11}}{|G|} & \frac{K_{21}}{|G|} & \frac{K_{31}}{|G|} \\
\frac{K_{12}}{|G|} & \frac{K_{22}}{|G|} & \frac{K_{32}}{|G|} \\
\frac{K_{13}}{|G|} & \frac{K_{23}}{|G|} & \frac{K_{33}}{|G|}
\end{array}\right]
$$

Dengan mensubstitusikan persamaan (12) kedalam persamaan (11), maka dapat paramater $a, b$, dan $c$ dapat diketahui.

$$
\left[\begin{array}{l}
a \\
b \\
c
\end{array}\right]=\left[\begin{array}{lll}
\frac{K_{11}}{|G|} & \frac{K_{21}}{|G|} & \frac{K_{31}}{|G|} \\
\frac{K_{12}}{|G|} & \frac{K_{22}}{|G|} & \frac{K_{32}}{|G|} \\
\frac{K_{13}}{|G|} & \frac{K_{23}}{|G|} & \frac{K_{33}}{|G|}
\end{array}\right]\left[\begin{array}{c}
\sum_{i, j=1}^{N} G_{i j} x_{i} \\
\sum_{i, j=1}^{N} G_{i j} y_{j} \\
\sum_{i, j=1}^{N} G_{i j}
\end{array}\right]
$$

untuk memudahkan perhitungan maka disusun kembali persamaan diatas menjadi

$$
\left[\begin{array}{l}
a \\
b \\
c
\end{array}\right]=\left[\begin{array}{lll}
\frac{K_{11}}{|G|} & \frac{K_{21}}{|G|} & \frac{K_{31}}{|G|} \\
\frac{K_{12}}{|G|} & \frac{K_{22}}{|G|} & \frac{K_{32}}{|G|} \\
\frac{K_{13}}{|G|} & \frac{K_{23}}{|G|} & \frac{K_{33}}{|G|}
\end{array}\right]\left[\begin{array}{l}
D_{11} \\
D_{21} \\
D_{31}
\end{array}\right]
$$

dengan mensubtitusikan persamaan $K D$ dan $|G|$ maka parameter $a$, $b$, dan $c$ dapat ditentukan dengan persamaan berikut:

$$
\begin{gathered}
a=\frac{\left(N \sum_{j=1}^{N} y_{j}^{2}-\sum_{j=1}^{N} y_{j} \sum_{j=1}^{N} y_{j}\right) \sum_{i, j=1}^{N} G_{i j} x_{i}-\left(N \sum_{i, j=1}^{N} x_{i} y_{j}-\sum_{j=1}^{N} y_{j} \sum_{i=1}^{N} x_{i}\right) \sum_{i, j=1}^{N} G_{i j} y_{j}+\left(\sum_{i, j=1}^{N} x_{i} y_{j} \sum_{j=1}^{N} y_{j}-\sum_{j=1}^{N} y_{j}^{2} \sum_{i=1}^{N} x_{i}\right) \sum_{i, j=1}^{N} G_{i j}}{\sum_{i=1}^{N} x_{i}^{2}\left(N \sum_{j=1}^{N} y_{j}^{2}-\sum_{j=1}^{N} y_{j} \sum_{j=1}^{N} y_{j}\right)-\sum_{i, j=1}^{N} x_{i} y_{j}\left(N \sum_{i, j=1}^{N} x_{i} y_{j}-\sum_{j=1}^{N} y_{j} \sum_{i=1}^{N} x_{i}\right)+\sum_{i=1}^{N} x_{i}\left(\sum_{i, j=1}^{N} x_{i} y_{j} \sum_{j=1}^{N} y_{j}-\sum_{i=1}^{N} x_{i} \sum_{j=1}^{N} y_{j}^{2}\right)} \\
b=\frac{-\left(N \sum_{i, j=1}^{N} x_{i} y_{j}-\sum_{i=1}^{N} x_{i} \sum_{j=1}^{N} y_{j}\right) \sum_{i, j=1}^{N} G_{i j} x_{i}-\left(N \sum_{i=1}^{N} x_{i}^{2}-\sum_{i=1}^{N} x_{i} \sum_{i=1}^{N} x_{i}\right) \sum_{i, j=1}^{N} G_{i j} y_{j}+\left(\sum_{i=1}^{N} x_{i}^{2} \sum_{j=1}^{N} y_{j}-\sum_{i, j=1}^{N} x_{i} y_{j} \sum_{i=1}^{N} x_{j}\right)_{i, j=1}^{N} G_{i j}}{\sum_{i=1}^{N} x_{i}^{2}\left(N \sum_{j=1}^{N} y_{j}^{2}-\sum_{j=1}^{N} y_{j} \sum_{j=1}^{N} y_{j}\right)-\sum_{i, j=1}^{N} x_{i} y_{j}\left(N \sum_{i, j=1}^{N} x_{i} y_{j}-\sum_{j=1}^{N} y_{j} \sum_{i=1}^{N} x_{i}\right)+\sum_{i=1}^{N} x_{i}\left(\sum_{i, j=1}^{N} x_{i} y_{j} \sum_{j=1}^{N} y_{j}-\sum_{i=1}^{N} x_{i} \sum_{j=1}^{N} y_{j}^{2}\right)} \\
c=\frac{\left(\sum_{i, j=1}^{N} x_{i} y_{j} \sum_{j=1}^{N} y_{j}-\sum_{i=1}^{N} x_{i} \sum_{j=1}^{N} y_{j}^{2} \sum_{i, j=1}^{N} G_{i j} x_{i}-\left(\sum_{i=1}^{N} x_{j}^{2} \sum_{j=1}^{N} y_{j}-\sum_{i=1}^{N} x_{i} \sum_{j=1}^{N} y_{j} \sum_{i=1}^{N} x_{i}\right) \sum_{i, j=1}^{N} G_{i j} y_{j}+\left(\sum_{i=1}^{N} x_{j}^{2} \sum_{j=1}^{N} y_{j}^{2}-\sum_{i, j=1}^{N} x_{i} y_{j} \sum_{i, j=1}^{N} x_{i} y_{j}\right) \sum_{i, j=1}^{N} G_{i j}\right.}{\sum_{i=1}^{N} x_{i}^{2}\left(N \sum_{j=1}^{N} y_{j}^{2}-\sum_{j=1}^{N} y_{j} \sum_{j=1}^{N} y_{j}\right)-\sum_{i, j=1}^{N} x_{i} y_{j}\left(N \sum_{i, j=1}^{N} x_{i} y_{j}-\sum_{j=1}^{N} y_{j} \sum_{i=1}^{N} x_{i}\right)+\sum_{i=1}^{N} x_{i}\left(\sum_{i, j=1}^{N} x_{i} y_{j} \sum_{j=1}^{N} y_{j}-\sum_{i=1}^{N} x_{i} \sum_{j=1}^{N} y_{j}^{2}\right)}
\end{gathered}
$$


Paramater $a, b$, dan $c$ yang telah didapatkan kemudian disubtitusikan kedalam persamaan (2) untuk mendapatkan nilai gaya berat regional dan menggunakan persamaan (1) untuk mendapatkan nilai gaya berat residual.

\section{Metode Penelitian}

Penelitian dilakukan dengan melakukan beberapa tahap percobaan. Tahap pertama adalah menguji metode trend surface analysis pada data sintetis dengan tujuan mengetahui performa dari metode ini sebelum kemudian diterapkan pada data lapangan. Setelah diuji pada data sintetis maka metode trend surface analysis diterapkan pada data lapangan. Data lapangan gayaberat yang digunakan adalah data gayaberat yang berlokasi di sekitar kampus ITERA.

\section{Aplikasi pada Data Sintetis}

Data sintetis dibuat dengan beberapa jenis model. Model pertama (Gambar 1) dibuat dengan sederhana yang terdiri dari dua sumber anomali. Kemudian dengan menambahkan kompleksitas maka dibuat model kedua yang terdiri dari beberapa sumber anomali.

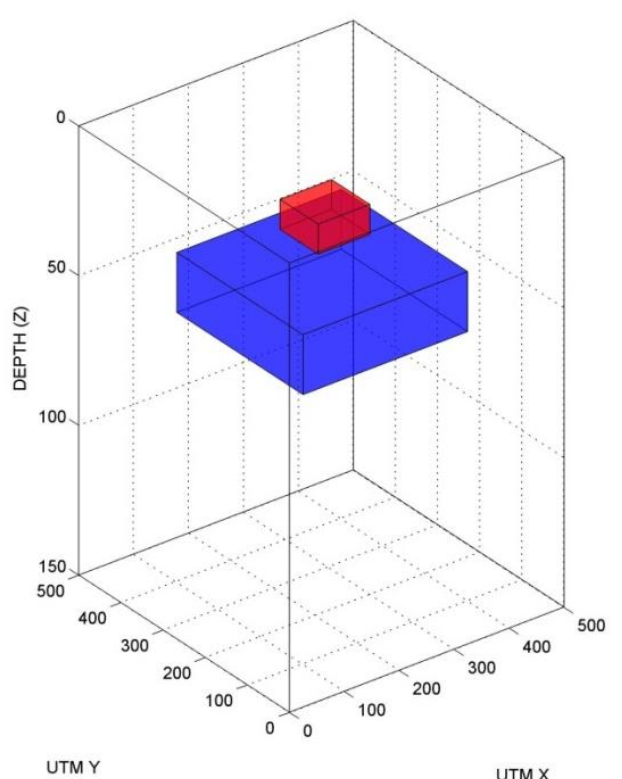

Gambar 1. Model Sintetik A
Anomali regional merupakan anomali yang merepresentasikan sumber anomali yang relatif dalam dan besar, pada model sintetik anomali regional ditunjukan oleh sumber anomali yang berwarna biru pada Gambar 1. Sedangkan untuk anomali residual adalah sumber anomali yang relatif lebih dangkal dan memiliki ukuran yang kecil. Pada model sintetis di Gambar 1 anomali residual ditunjukan oleh benda yang berwarna merah.

Berdasarkan model sintetik A kemudian dihitung respon modelnya (Gambar 2) dengan menggunakan persamaan pemodelan kedepan gayaberat sehingga didapatkan nilai anomali gayaberatnya.

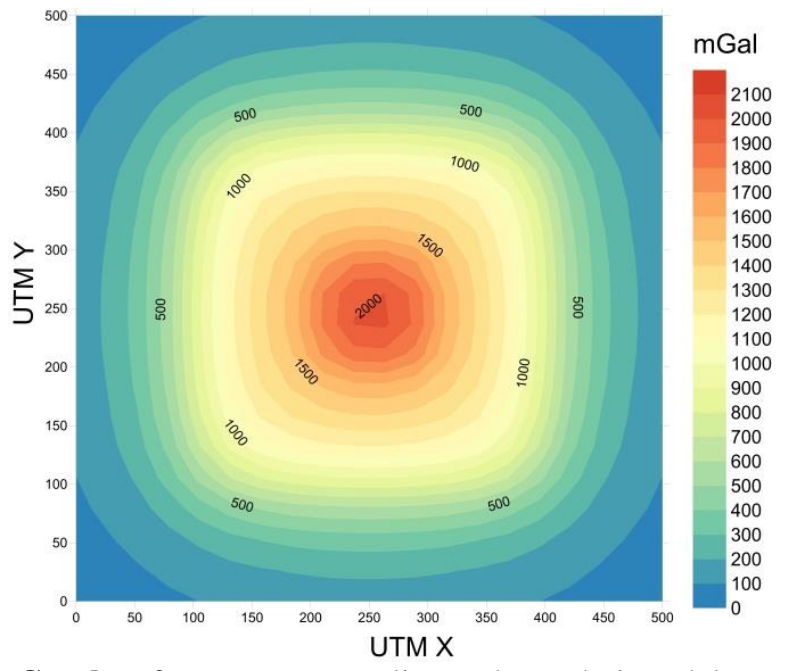

Gambar 2. Respon anomali gaya berat dari model sintetis A

Data sintetik yang telah dibuat kemudan diterapkan metode pemisahan anomali trend surface analysis. Perhitungan yang telah dilakukan didapatkan parameter $a, b$, dan $c$ memiliki nilai $0,0039,-0,0396$, dan 583,2292 berturut-turut. Nilai parameter $a$, $b$, dan $c$ kemudian disubtitusikan kedalam persamaan (2) dan persamaan (1) untuk kemudian dilakukan pemisahan anomali regional dan residual. Hasilnya pada Gambar 3. 


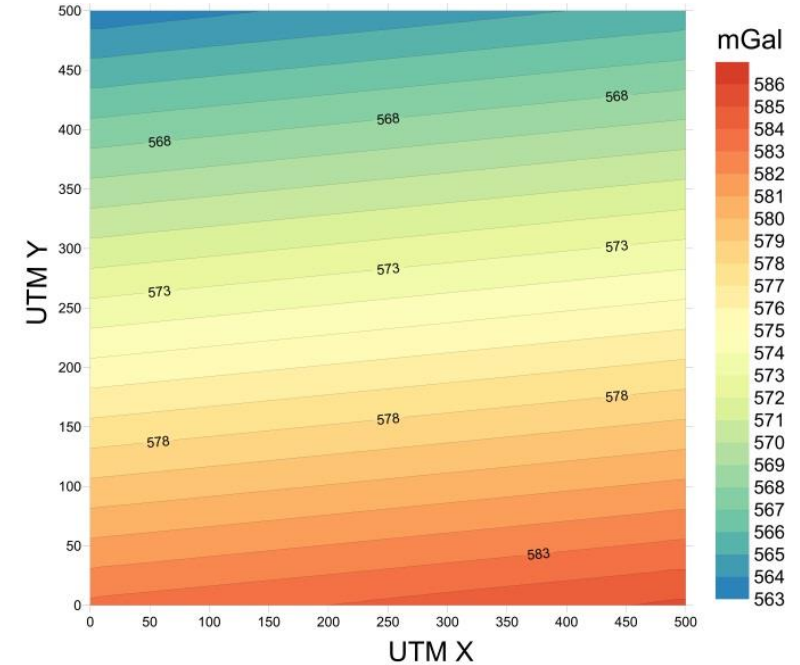

Gambar 3. Anomali regional gayaberat hasil dari pemisahan anomali dengan penerapan metode trend surface analysis. Didapatkan nilai anomali rendah di utara yang ditandai oleh warna biru dan anomali tinggi ditandai dengan warna merah.

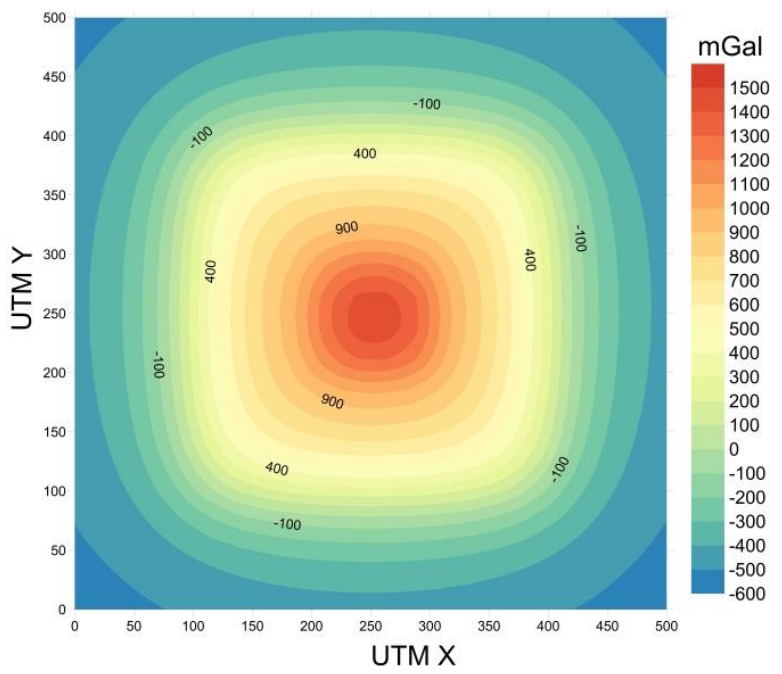

Gambar 4. Anomali residual hasil perhitungan dengan menggunakan metode trend surface analysis

Anomali yang muncul pada peta anomali residual pada Gambar 4 merupakan nilai anomali yang diakibatkan oleh sumber anomali yang dangkal dan kecil. Anomali residual dapat dibagi menjadi dua klasifikasi, antara lain nilai anomali bernilai positif dan nilai anomali bernilai negatif. Nilai anomali negatif merupakan nilai anomali yang tidak memiliki sumber anomali, dapat dilihat pada model sintetik pada Gambar 1, disekitar sumber anomali dangkal yang berwarna merah tidak terdapat sumber anomali lain atau sumber anomali yang memiliki densitas. Nilai anomali positif adalah sumber anomali yang memiliki kontras, maka karena sumber anomali tersebut berada pada kedalaman yang dangkal, sumber anomali tersebut dapat terlihat pada peta anomali residual.

Guna menambahkan kompleksitas dan menguji kembali metode trend surface analysis pada area yang lebih kompleks maka dibuat kembali data sintetis dengan menambahkan kempleksitas pada modelnya.

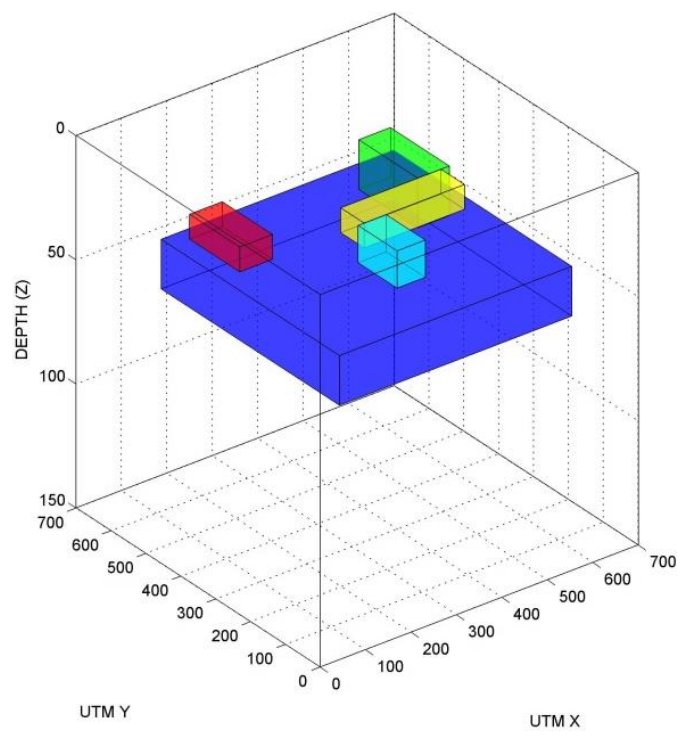

Gambar 5. Model Sintetik B

Pada model data sintetis ini dibuat dengan lima sumber anomali dengan empat sumber anomali berada pada kedalaman dangkal dan memiliki ukuran kecil yang dianggap sebagai sumber anomali residual dan satu sumber anomali yang dalam dan memiliki ukuran besar yang kemudian dianggap sebagai sumber anomali regional.

Model sintetik B (Gambar 5) kemudian dihitung respon modelnya sehingga didapatkan nilai anomali gayaberatnya. Respon anomali gayaberat yang didapatkan merupakan akumulasi dari semua sumber anomali yang dimiliki pada model sintetik $\mathrm{B}$, sehingga sumber anomali yang dianggap sebagai sumber anomali regional dan sumber anomali residual muncul pada data anomali gayaberat. 


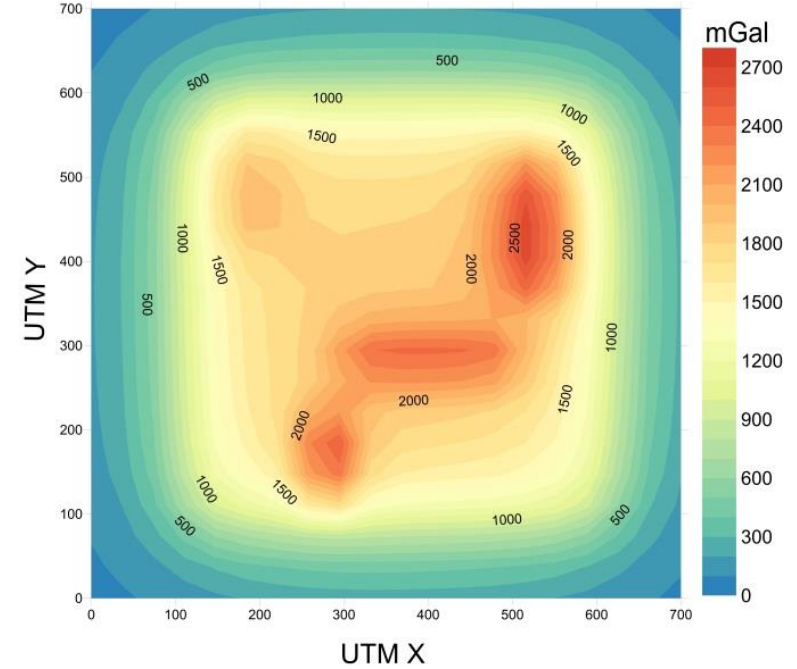

Gambar 6. Respon anomali gayaberat dari model sintetik B.

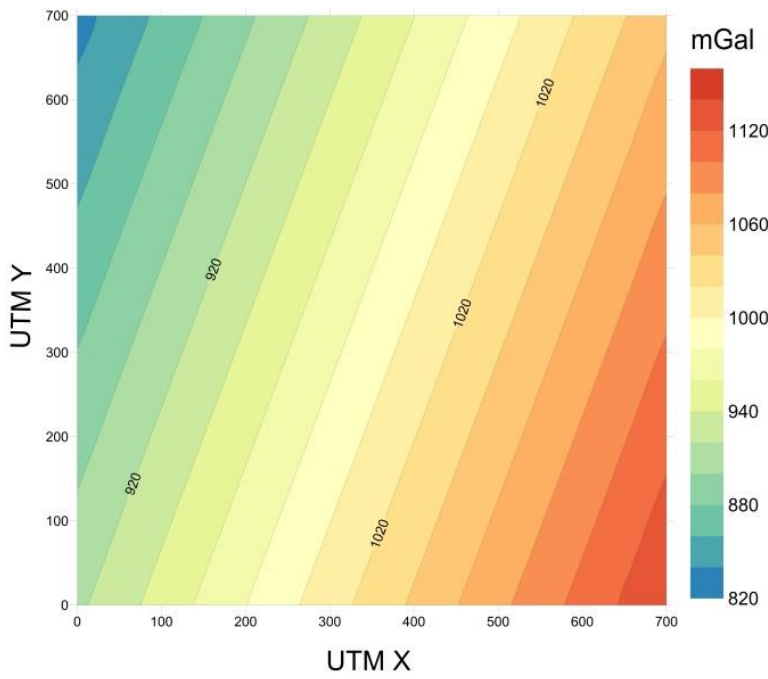

Gambar 7. Anomali regional hasil penerapan metode trend surface analysis

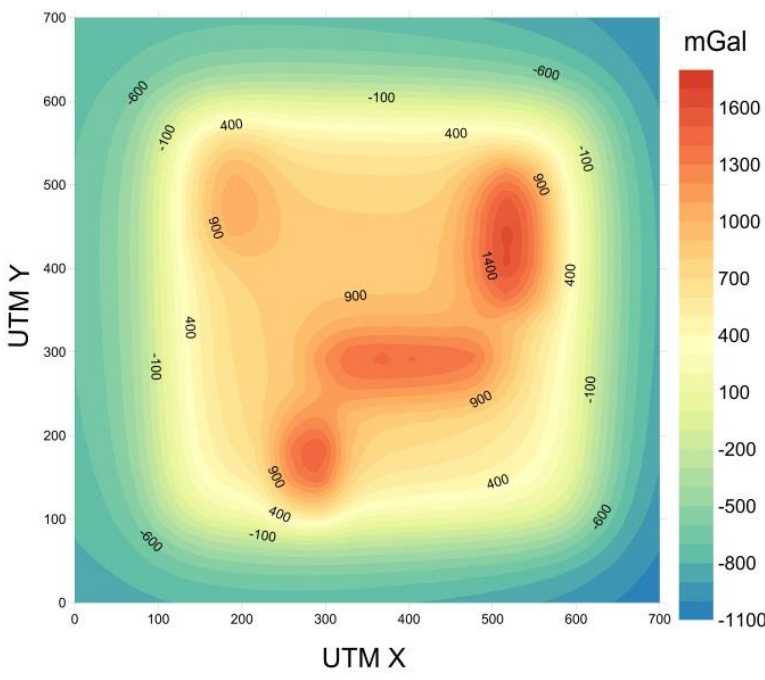

Gambar 8. Anomali residual hasil penerapan metode trend surface analysis
Pengujian metode trend surface analysis diterapkan pada data anomali respon gayaberat hasil perhitungan model sintetik B (Gambar 6). Sama seperti pengujian pada model sintetik A, hasil dari metode trend surface analysis adalah dua jenis peta anomali gayaberat, yaitu anomali regional dan anomali residual.

Berdasarkan hasil pemisahan respon anomali gayaberat dengan menerapkan metode trend surface analysis didapatkan dua jenis anomali gayaberat, yaitu anomali regional gayaberat dan anomali residual gayaberat. Anomali regional gayaberat memperlihatkan trend anomali yang muncul, terlihat Gambar 7 trend anomali yang muncul berarah cenderung timur-laut barat-daya, hal ini juga tercermin pada model sintetik B pada Gambar 5 yang memperlihatkan kecenderungan keberadaan sumber anomali yang berarah timur-laut barat-daya. Anomali regional hasil perhitungan trend surface analysis masih relatif memiliki respon anomali residual sehingga belum menghilangkan secara total sumber anomali residualnya, sehingga trend anomali yang muncul masih memiliki efek dari sumber anomali yang dangkal atau anomali residual.

Anomali residual gayaberat pada Gambar 8 memperlihatkan anomali yang muncul akibat sumber anomali yang berada pada kedalaman dangkal seperti tercermin pada model sintetis gayaberat pada Gambar 5. Anomali residual ini dapat dibagi menjadi dua klasifikasi, yaitu anomali yang bernilai positif dan anomali yang bernilai negatif. Anomali negatif merupakan nilai anomali yang tidak terdapat sumber anomali, dibuktikan pada model sintetik B pada kedalaman relatif dangkal tidak terdapat sumber anomali. Anomali yang bernilai positif merupakan nilai anomali yang terdapat sumber anomali, hal ini terbukti pada model sintetik B, pada kedalaman yang relatif dangkal terdapat sumber anomali. 
Posisi sumber anomali pada model sintetik B dapat dengan jelas terlihat pada peta anomali residual. Oleh karena itu metode ini dapat disimpulkan bahwa hasil anomali residualnya mampu untuk memunculkan posisi sumber anomali yang berada pada kedalaman dangkal dan meminimalkan sumber anomali yang berada pada kedalaman dalam. Hasil anomali residual ini berbanding terbalik dengan hasil anomali regional. Anomali regional dengan metode ini masih belum mampu menghitung sumber anomali yang berada pada kedalaman yang dalam, sehingga masih memiliki efek dari sumber anomali yang berada pada kedalaman dangkal. Hasil pengujian metode ini kemudian diterapkan pada data gayaberat hasil pengukuran di lapangan.

\section{Aplikasi pada Data Lapangan}

Berdasarkan pengujian metode pemisahan anomali trend surface analysis didapatkan kesimpulan bahwa metode ini cukup baik dalam memunculkan sumber anomali pada kedalaman dangkal atau anomali residual meskipun kurang baik dalam menghitung sumber anomali pada kedalaman dalam atau anomali regional.

Metode trend surface analysis kemudian diterapkan pada data lapangan. Data lapangan yang digunakan adalah data anomali gayaberat yang berlokasi disekitar kampus ITERA. Hasil dari pengukuran lapangan adalah data anomali gayaberat lengkap atau anomali Bouguer. Data anomali Bouguer yang didapatkan di lapangan merupakan data yang sudah dilakukan koreksi, sehingga anomali yang muncul merupakan nilai anomali yang disebabkan oleh sumber anomali yang berada di bawah permukaan.

Pada Gambar 9 dapat dilihat merupakan peta anomali Bouguer lengkap daerah pengukuran yang memiliki trend anomali berarah barat daya- timur laut. Arah trend tersebut memisahkan dua jenis kelompok anomali, yaitu anomali tinggi pada arah tenggara dan anomali rendah pada arah barat laut. Anomali Bouguer lengkap kemudian dilakukan pemisahan anomali regional dan anomali residual dengan menggunakan trend surface analysis. Berdasarkan uji coba metode ini pada data sintetis menghasilkan kesimpulan bahwa anomali regional yang muncul masih memiliki efek dari anomali residual. Berdasarkan fakta tersebut dapat ditebak bahwa anomali regional yang muncul akan memiliki trend anomali regional yang tidak jauh berbeda dengan trend anomali Bouguer lengkap.

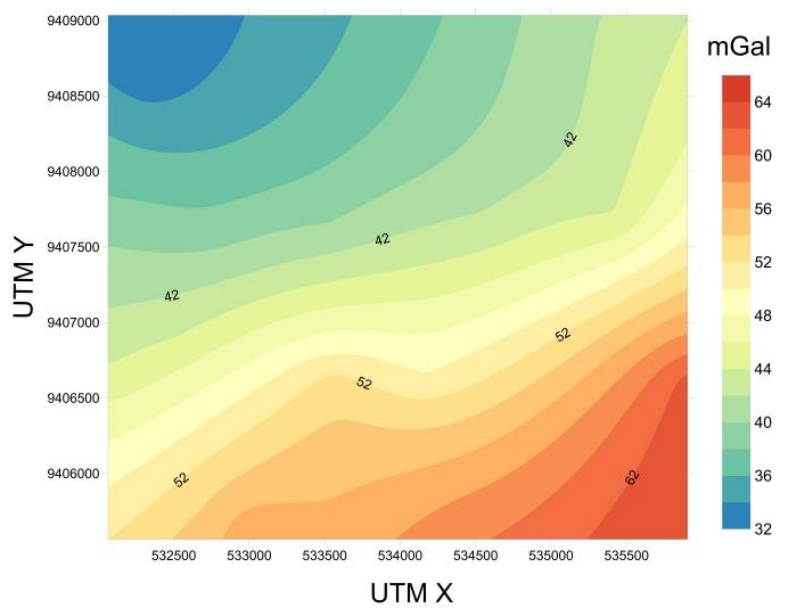

Gambar 9. Peta anomali Bouguer lengkap daerah pengukuran.

Setelah dilakukan pemisahan anomali dengan menerapkan metode trend surface analysist didapatkan dua jenis anomali, yaitu peta anomali regional pada Gambar 10 dan peta anomali residual pada gambar 11. Anomali regional pada Gambar 10 dapat dilihat memiliki trend arah anomali yang tidak jauh berbeda dengan anomali Bouguer lengkap pada Gambar 9 yaitu berarah barat daya - timur laut. Meski trend arah kedua anomali tersebut cenderung mirip, tetapi jika diamati lebih detail terdapat perbedaan frekuensi anomali, dimana frekuensi anomali regional lebih rendah dibandingkan dengan frekuensi anomali Bouguer. Frekuensi anomali yang rendah pada anomali regional dibuktikan dengan garis kontur anomali yang cenderung garis lurus. Hal ini menunjukan 
panjang gelombang yang besar pada peta anomali regional, konsekuensi dari panjang gelombang yang besar adalah frekuensi yang kecil. Garis yang cenderung lurus pada anomali regional tidak ditemukan pada anomali Bouguer lengkap, hal menunjukan panjang gelombang pada anomali Bouguer lengkap lebih kecil dibanding anomali regional, konsekuensi dari panjang gelombang yang kecil adalah memiliki frekuensi yang tinggi, hal ini terjadi karena anomali Bouguer lengkap masih memiliki efek dari sumber anomali yang memiliki frekuensi rendah.

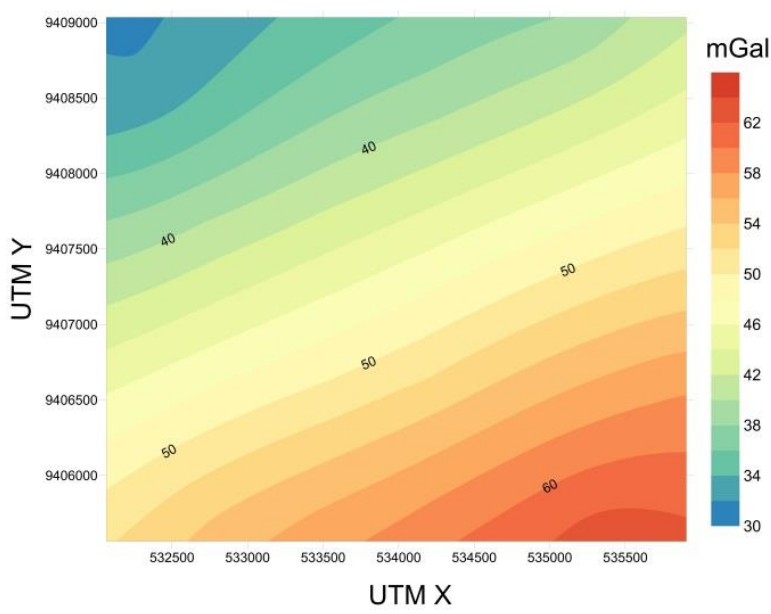

Gambar 10. Peta anomali regional hasil penerapan metode trend surface anaysist pada data anomali Bouguer lengkap

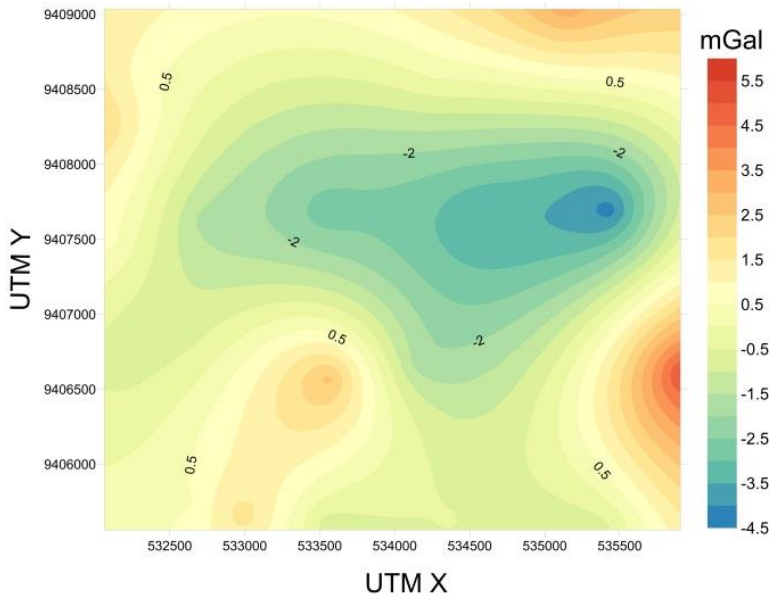

Gambar 11. Peta anomali residual hasil penerapan metode trend surface analysist pada data anomali Bouguer lengkap

Pemisahan anomali Bouguer lengkap juga menghasilkan anomali residual. Peta anomali residual dapat dilihat pada gambar
11. Peta anomali residual sudah memiliki trend anomali yang sudah sangat berbeda dari anomali regional maupun anomali Bouguer lengkap, hal ini terjadi karena anomali residual hanya memunculkan efek dari sumber anomali yang berada pada kedalaman dangkal dan berukuran kecil. Jika diamati frekuensi anomalinya pun memiliki frekuensi yang sangat tinggi, dibuktikan dengan adanya klosur-klosur anomali yang bernilai positif dan negatif.

\section{Diskusi}

Metode trend surface analysis merupakan salah satu dari sekian banyak metode pemisahan anomali. Metode ini telah dilakukan pengujian pada data sintetis. Proses ini melibatkan perhitungan kedepan atau forward modelling untuk mendapatkan respon anomali gayaberat yang diinginkan. Pengujian dilakukan terhadap dua jenis model yang berbeda. Model pertama dilakukan dengan menggunakan model sederhana yang dihasilkan dari dua buah sumber anomali, yaitu anomali dalam dan anomali dangkal. Hasil dari pengujian pada anomali yang sederhana ini dapat dibuat kesimpulan sementara bahwa anomali residual yang muncul adalah anomali yang dihasilkan akibat model sumber anomali yang berada pada kedalaman dangkal, sedangkan anomali regional belum dapat dibuat kesimpulan.

Pengujian kedua dilakukan dengan menambahkan kompleksitas terhadap model sumber anomali. Model kedua ini dibuat dengan membuat lima sumber anomali, satu sumber anomali yang berada pada kedalaman dalam dan memiliki ukuran yang besar dan empat model sumber anomali lainnya dibuat pada kedalaman dangkal dan memiliki ukuran yang kecil. Posisi dari model sumber anomali dangkal dibuat memiliki arah yang cenderung memiliki trend barat daya - timur laut. Hasil penerapan metode trend surface analysis didapatkan anomali residual yang memunculkan sumber anomali akibat 
model sumber anomali pada kedalaman dangkal, dimana terdapat empat sumber anomali dapat dilihat pada Gambar 8 . Sedangkan anomali regional yang muncul memiliki trend anomali berarah barat daya - timur laut, sehingga anomali regioal hasil trend surface analysis masih memiliki efek akibat sumber anomali yang berada pada kedalaman dangkal.

Setelah didapatkan kesimpulan maka metode trend surface analysis diterapkan pada data lapangan. Hasilnya menunjukan hal yang sama dengan pengujian pada data sintetis. Anomali regional masih memiliki trend yang sama mirip dengan anomali Bouguer lengkap, anomali ini masih memiliki efek akibat sumber anomali pada kedalaman dangkal. Hasil yang berbeda pada anomali residual, anomali residual hasil pemisahan anomali dengan trend surface analysist sudah sangat memunculkan sumber anomali yang berada pada kedalaman dangkal.

\section{Kesimpulan}

Berdasarkan pengujian pada data sintetik dan data lapangan dapat diambil kesimpulan bahwa metode pemisahan trend surface analysist memiliki performa yang baik untuk memunculkan anomali akibat sumber anomali pada kedalaman dangkal atau untuk mendapatkan anomali residual. Hal ini dibuktikan dengan baik pada model sintetik maupun data lapangan bahwa anomali residual yang dihasilkan metode ini sudah mencerminkan dan merepresentasikan sumber anomali pada kedalaman dangkal.

Anomali regional yang dihasilkan dari metode ini memiliki hasil yang kurang begitu baik, dapat dilihat pada pengujian pada data sintetik maupun pada data lapangan. Hal ini terjadi karena anomali regional yang muncul dari metode ini masih memiliki efek dari sumber anomali pada kedalaman dangkal atau sumber anomali residual.

\section{Ucapan Terimakasih}

Terimakasih kepada mahasiswa Teknik Geofisika ITERA yang sudah melakukan pengukuran data lapangan.

\section{Daftar Pustaka}

Abdelrahman, E.M., Riad, S., Refai, E. and Amin, Y. 1985. On the leastsquares residual anomaly determination. Geophysics. 50(3), pp.473-480. doi: 10.1190/1.1441925.

Abokhodair, A.A. 2011. Constrained polynomial fitting for recovery of regional gravity. Geophysical Prospecting. 59(4), pp.749-759. doi: $\quad 10.1111 / \mathrm{j} .1365$ 2478.2011.00945.x.

Beltrao, J. F., Silva, J.B.C. and Costa, J.C. 1991. Robust polynomial fitting method for regional gravity estimation. Geophysics. 56(1), pp.80-89. doi: 10.1190/1.1442960.

Blakely, R.J. 1995. Potential Theory in Gravity and Magnetic. doi: 10.1017/CBO9780511549816.

Davis, J.C. 2002. Statistics and Data Analysis in Geology -Wiley (2002).pdf.

Grandis, H. and Dahrin, D. 2014. Constrained Two-Dimensional Inversion of Gravity Data. Journal of Mathematical and Fundamental Sciences. 46(1), pp.1-13. doi: 10.5614/j.math.fund.sci.2014.46.1. 1.

Guo, L., Meng, X., Chen, Z., Li, S. and Zheng, Y. 2013. Preferential filtering for gravity anomaly separation. Computers and Geosciences. 51, pp.247-254. doi: 10.1016/j.cageo.2012.09.012.

Gupta, V. K. and Ramani, N. 1980. Some aspects of regional-residual separation of gravity anomalies in a Precambrian terrain. Geophysics. 45(9), pp.1412-1426. doi: 10.1190/1.1441130. 
Keating, P. and Pinet, N. 2011. Use of nonlinear filtering for the regionalresidual separation of potential field data. Journal of Applied Geophysics. 73(4), pp.315-322. doi:

10.1016/j.jappgeo.2011.02.002.

Martín, A., Núñez, M.A., Gili, J.A. and Anquela, A.B. 2011. A comparison of robust polynomial fitting, global geopotential model danspectral analysis for regional-residual gravity field separation in the Doñana National Park (Spain). Journal of Applied Geophysics. 75(2), pp.327-337. doi: 10.1016/j.jappgeo.2011.06.037.

Menke, W. 2012. Geophysical Data Analysis: Discrete Inverse Theory. New York: Academic Press. doi: 10.1016/b978-0-12-3971609.00001-1.

Nettleton, L.L. 2014. Elementary Gravity and Magnetics for Geologists and Seismologists. doi: 10.1190/1.9781560802433.

Nishijima, J. and Naritomi, K. 2017. Interpretation of gravity data to delineate underground structure in the Beppu geothermal field, central Kyushu, Japan. Journal of Hydrology: Regional Studies. 11, pp.84-95. doi: 10.1016/j.ejrh.2015.11.022.

Obasi, A.I., Onwuemesi, A.G. and Romanus, O.M. 2016. An enhanced trend surface analysis equation for regional-residual separation of gravity data. Journal of Applied Geophysics. 135, pp.90-99. doi: 10.1016/j.jappgeo.2016.09.023.

Pawlowski, R.S. and Hansen, R.O. 2002. Gravity anomaly separation by Wiener filtering. Geophysics. 55(5), pp.539-548. doi: 10.1190/1.1442865.

Selim, E.S.I. and Aboud, E. 2014. Application of spectral analysis technique on ground magnetic data to calculate the Curie depth point of the eastern shore of the Gulf of Suez, Egypt. Arabian Journal of Geosciences. 7(5), pp.1749-1762. doi: 10.1007/s12517-013-0868-7.

Shuey, R.T., Schellinger, D.K., Tripp, A.C. and Ai, L.B. 1977. Curie depth determination from aeromagnetic spectra. Geophysical Journal of the Royal Astronomical Society. 50(1), pp.75-101. doi: 10.1111/j.1365246X.1977.tb01325.x.

Simpson, S.M. 1954. Least Squares Polynomial Fitting to Gravitational Data and Density Plotting By Digital Computers. Geophysics. pp.255-269. doi: 10.1190/1.1437990.

Skeels, D.C. 1967. What is residual gravity. Geophysics. 32(5), pp.872-876. doi: 10.1190/1.11439896

Spector, A. and Grant, F.S. 1970. Statistical models for interpreting aeromagnetic data. Geophysics. 35(2), pp.239-302. doi: 10.1190/1.1440092

Unwin, D. 1978. An introduction to trend surface analysis. Concepts and techniques in modern geography, 5 , pp.1-40.

Xu, W. and Chen, S. 2018. A case study of forward calculations of the gravity anomaly by spectral method for a three-dimensional parameterised fault model. Computers and Geosciences. 111 (September 2017), pp.67-77. doi: 10.1016/j.cageo.2017.11.001.

Xu, Y., Hao, T., Li, Z., Duan, Q. and Zhang, L. 2009. Regional gravity anomaly separation using wavelet transform and spectrum analysis. Journal of Geophysics and Engineering. 6(3), pp.279-287. doi: 10.1088/17422132/6/3/007. 